\title{
Determination of Transmission Coefficient for the Filtration Deposit Made of Coal Grains
}

\section{Introduction}

Filtration presses are commonly used in water and sludge circulations of industrial plants, in particular in mechanical processing plants of coal and other fossil fuels (Piecuch 2009, 2010). Filtration processes may be generally divided into vacuum filtration, pressure filtration and centrifugal filtration as typical for water-sludge circulations in mechanical processing plants of mineral resources (Dahlstrom 1954). Obviously, special filtration processes, that is microfiltration and ultrafiltration, are used in circulations of industrial plants (Ostrowska and others, 2013), including in widely understood water conditioning plants (Aniszewski 2013; Guang-Wei et al 2015; Kabsch-Korbutowicz and Urbanowska 2009; Kliber and Wiśniewski 2009; Rychlewska et al. 2015; Tomaszewska 2011). Due to their special course, these processes have not been mentioned in the above systematics of filtration processes.

With reference to, for example, coal mechanical processing plants, mainly vacuum filters and filtration presses are used (Piecuch 2009, 2010). However, certain general conditions of feed properties shall be observed, as the feed determines when and which filtration processes can be applied (Dahlstrom 1954; Piecuch 2009, 2010). Here you should note that most frequently the sorption process (which is not discussed in this publication) is associated with the filtration process to a greater or smaller degree (Gumińska 2007; Hewelke and others 2014). The equipment for vacuum filtration, that is vacuum filters and equipment for

* Professor, ** D.Sc., *** M.Sc. Eng., Faculty of Civil Engineering, Environmental and Geodetic Sciences Koszalin University of Technology, Koszalin, Poland; e-mail: tadeusz.piecuch@tu.koszalin.pl 
pressure filtration, i.e. filtration presses, constitute an expensive capital expenditure and are also expensive in operation (Piecuch 2009, 2010). Therefore, you cannot exclude that in the future, in order to reduce the unit price of the final product, which is a ton of the sold coal, you may consider a non-standard - for today's conditions of dewatering of coal suspensions (e.g. the waters used after pulsator jigs) - gravitational filtration (that is filtration under own pressure) of coal suspensions fed to the post-production process (Piekarski 2010).

To this end you can consider including a filtration surface in the tight housing with the deposit spilt on the filtration mesh, to which a post-production coal suspension will be fed. This deposit will be selected taking into account its granulation, so that considering the feed's grain size you can retain the whole suspension on the deposit, or finally partly on the deposit and partly inside the deposit, filling its pores (silting-up phenomenon - Piekarski 2011). It is assumed that after the completed process of deposit filtration, the dumped stopping, that is the deposit made of coal grains and sediment, will be tilted - mechanically raised vertically, and that in this moment the deposit, together with the sediment, will gravitationally drop on a conveyor or truck - diagram, Figure 1.

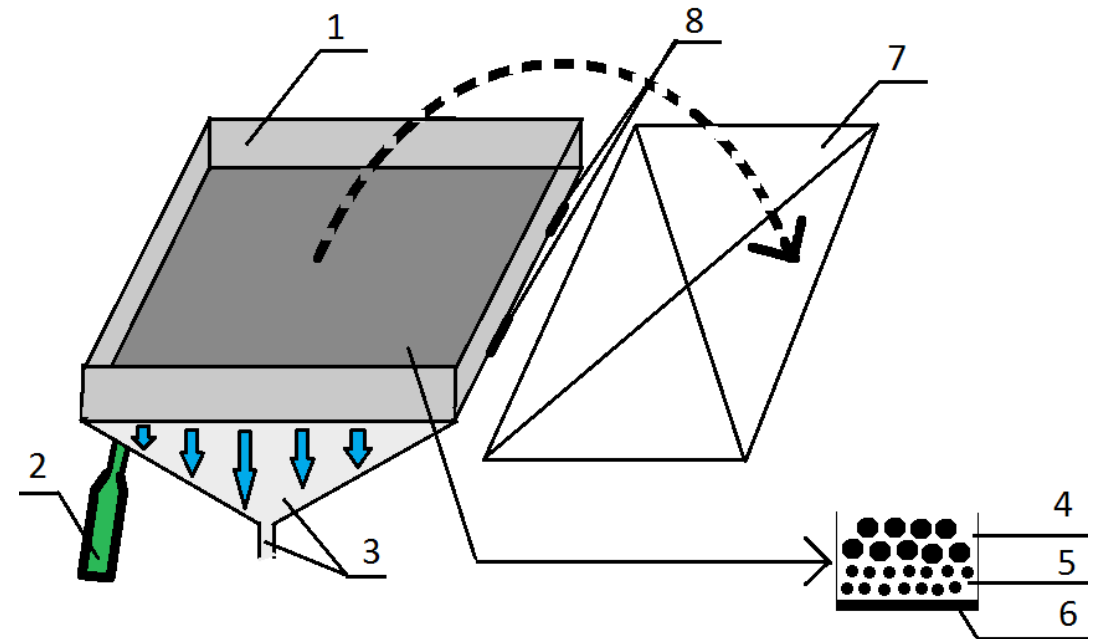

Fig 1. Diagram of gravitational deposit filter

1 - housing, 2 - conveyor, 3 - filtrate outflow, 4 - sediment layer, 5 - filtration (coal) deposit, 6 - filtration mesh, 7 - space for a truck, 8 - hinges

Rys. 1. Schemat filtra grawitacyjnego złożowego

1 - obudowa, 2 - podnośnik, 3 - odpływ filtratu, 4 - warstwa osadu, 5 - złoże filtracyjne (węglowe), 6 - siatka filtracyjna, 7 - miejsce na samochód ciężarowy, 8 - zawiasy)

Obviously the disadvantage of such a solution from its technological side is that there must be a lot of surfaces of gravitational deposit filter, but - in terms of capital expenditure and operation - these are surely smaller costs.

As part of this publication we will discuss tests with basic character of the process of gravitational flow of the liquid through the porous deposit made of the layer of coal grains. 


\section{Own theoretical analysis as well as tests used to determine transmission coefficient}

\subsection{Theoretical analysis}

In order to conduct the below-mentioned theoretical analysis aimed at determination of transmission coefficient, we should start with the general filtration equation as shown below - equation 1 .

$$
\dot{V}=\frac{\Delta p}{R_{S}+R_{Z}+R_{O}}
$$

The above-mentioned equation 1 was completed by Piecuch $(2009,2010)$ to include the provisions of individual resistances of respectively filtration mesh $R_{S}$, deposit $R_{Z}$ and sediment $R_{O}$.

General resistance of sediment $R_{O}\left[\mathrm{~N} \cdot \mathrm{s} / \mathrm{m}^{5}\right]$ can be recorded according to Piecuch (2009, 2010) as below - equation 2 .

$$
R_{O}=\frac{\mu}{b_{1}} \cdot \frac{\beta_{N} \cdot V}{A^{2} \cdot \delta_{S} \cdot\left(1-\varepsilon_{2}\right)}
$$

After substituting equation (2) with equation (1) and conversion you can determine constant $b_{1}\left[\mathrm{~m}^{2}\right]$ as in equation 3 below:

$$
b_{1}=\frac{\mu \cdot \beta_{N} \cdot V}{A^{2} \cdot \delta_{S} \cdot\left(1-\varepsilon_{2}\right) \cdot\left(\frac{\Delta p}{\dot{V}}-R_{S}-R_{Z}\right)}
$$

General resistance of the mesh $R_{S}\left[\mathrm{~N} \cdot \mathrm{s} / \mathrm{m}^{5}\right]$ and general resistance of the deposit $R_{Z}\left[\mathrm{~N} \cdot \mathrm{s} / \mathrm{m}^{5}\right]$ are described by the below-mentioned equations 4 and 5 according to Darcy and Kozeny-Carman, where $\mathrm{k}$ is designated as Kozeny constant in the literature:

$$
R_{S}=t^{\prime} \cdot \frac{\mu}{A}
$$

After substituting equation (4) and equation (5) with equation (3) we receive general notation for determination of constant $b_{1}$ appearing in the general equation for resistance of sediment $R_{O}$ present in equation 2 .

Hence the equation for calculating constant $b_{1}\left[\mathrm{~m}^{2}\right]$ shall have the below-mentioned form - equation 6 : 


$$
b_{1}=\frac{\mu \cdot \beta_{N} \cdot V}{A^{2} \cdot \delta_{S} \cdot\left(1-\varepsilon_{2}\right) \cdot\left(\frac{\Delta p}{\dot{V}}-t^{\prime} \cdot \frac{\mu}{A}-\frac{\mu}{b_{2}} \cdot \frac{(1-\varepsilon)^{2}}{\varepsilon^{3} \cdot k} \cdot \frac{L_{1}}{A}\right)}
$$

Then after simplification of equation (6) you receive the below-mentioned notation used for calculation of constant $b_{1}\left[\mathrm{~m}^{2}\right]-$ equation 7 :

$$
b_{1}=\frac{\mu \cdot \beta_{N} \cdot V}{A^{2} \cdot \delta_{S} \cdot\left(1-\varepsilon_{2}\right) \cdot\left\{\frac{\Delta p}{\dot{V}}-\frac{\mu}{A}\left[t^{\prime} \cdot-\frac{(1-\varepsilon)^{2}}{\varepsilon^{3} \cdot k} \cdot \frac{L_{1}}{b_{2}}\right]\right\}}
$$

$\stackrel{4}{\rightarrow} \mu-$ absolute viscosity $\left[\mathrm{N} \cdot \mathrm{s} / \mathrm{m}^{2}\right]$,

$\beta_{N}-$ compaction $\left[\mathrm{kg} / \mathrm{m}^{3}\right]$,

$V$ - volume $\left[\mathrm{m}^{3}\right]$,

$A$ - surface $\left[\mathrm{m}^{2}\right]$,

$\delta_{S}-$ specific gravity $\left[\mathrm{N} / \mathrm{m}^{3}\right]$,

$\varepsilon-$ deposit porosity [-],

$\varepsilon_{2}-$ sediment porosity [-],

$\Delta p-$ pressure $\left[\mathrm{N} / \mathrm{m}^{2}\right]$,

$\dot{V}-$ volume capacity $\left[\mathrm{m}^{3} / \mathrm{s}\right]$,

$k-$ Kozeny constant $[\mathrm{m} 2 / \mathrm{N}]$,

$L_{1}-$ deposit thickness [m],

$b_{2}-$ constant in the equation for deposit resistance RZ [N].

With regard to the above, in order to determine and calculate the value of constant $b_{1}$ we have to determine the value of constant $b_{2}$ beforehand, by conducting a relevant experiment consisting in flow of the liquid through the porous deposit.

\subsection{Own research}

In order to conduct the experiments, a column made of transparent plastic was prepared, with its working height of $2 \mathrm{~m}$, which was fixed on the tripod, with a filtration mesh $(0.2 \mathrm{~mm}$ metal mesh) installed from the bottom of the column, the mesh being interwoven with specially prepared mechanism blocking liquid outflow (cover). This lock made the zero start possible (after filling in the pipe with liquid) for each test. Upon unlocking (removing) the cover, the fluid (here liquid) flows through the porous layer.

Filtration deposit made of bituminous coal grains with the granulation from $0.35 \mathrm{~mm}$ to $0.315 \mathrm{~mm}$ was used for tests, while coal deposits with the thicknesses of 5 and $10 \mathrm{~cm}$ were used in the experiments. 
The experiments were conducted for two various volumes of mixture fed on the deposit, namely $1 \mathrm{dm}^{3}$ and $2 \mathrm{dm}^{3}$, which corresponded to specific pressure of the column of liquid. This pressure constituted filtration pressure (positive gauge pressure in relation to atmospheric pressure).

Obviously in zero - that is start - moment, when the height of the liquid column was the highest, pressure (product of the column's height and specific gravity of the liquid) was the highest and along with the process of liquid-fluid flow through the deposit made of coal grains the pressure was reducing. This loss of the column of liquid, and hence of the pressure, was observed and recorded during the experiment.

Hence average pressure was assumed for calculations, which resulted from half of the liquid column's height, as the calculated average pressure during the whole process of liquid flow through coal deposit. Calculation of coefficient $b_{2}$ for the porous deposit made of coal grains is the basic objective of research in this publication, apart from theoretical analysis, which shows how to calculate constant coefficient $b_{2}$.

\subsection{Examples of calculations}

The below-mentioned equation was used to calculate filtration constant $b_{2}$ for pressure of the liquid column resulting from the given volume of $1 \mathrm{dm}^{3}$ and deposit height $L=0.05 \mathrm{~m}$ :

$$
\dot{V}=\frac{\Delta p}{R_{S}+R_{Z}}
$$

from which deposit resistance was calculated:

$$
R_{Z}=\frac{\Delta p}{\dot{V}}-R_{S}
$$

and then after substituting specific values of parameters appearing in equation 9 the value of deposit resistance $R_{Z}$ equalling about $2.05 \cdot 10^{10} \mathrm{~N} \cdot \mathrm{s} / \mathrm{m}^{5}$ was received.

Subsequently, with the value of deposit resistance derived from the equation for deposit resistance as below:

$$
R_{Z}=\frac{\mu}{b_{2}} \cdot \frac{L_{1}}{A}
$$

on the basis of the above-mentioned equation 10 you can calculate the value of constant $b_{2}$, as all the remaining parameters of equation 10 are known.

The value of constant $b_{2}$ received from equation 10 amounted to about $9.91 \cdot 10^{-13} \mathrm{~N}$. 
Filtration constant $b_{2}$ calculated for the above-mentioned formula for the feed with the volume of $2 \mathrm{dm}^{3}$ and with deposit height of $L=0.1 \mathrm{~m}$ equalled about $2.37 \cdot 10^{-12} \mathrm{~N}$, while the calculated deposit resistance $R_{Z}$ amounted to about $1.72 \cdot 10^{10} \mathrm{~N} \cdot \mathrm{s} / \mathrm{m}^{5}$.

While analysing the above-mentioned results and referring to the methods of conducted tests one can notice that a mistake is made in the experiment, irrespective of the good will of persons conducting the tests. At the same time, it should be noted that the difference in the value of constant $b$ in both series of experiments on deposits with various heights and with various pressure of the liquid column is very small, considering extremely small numerical value of this constant.

The results of some of the conducted tests were presented in Figure 2. The diagram in Figure 2 presents an average value of the speed of liquid-fluid flow through the porous deposit made of coal grains, depending on the volume of fed liquid and the thickness of the porous deposit layer.

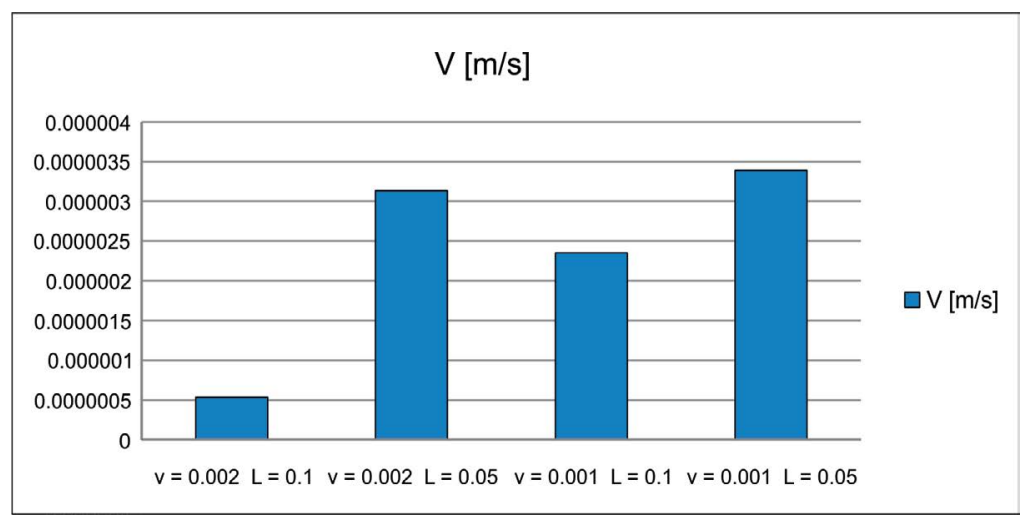

Fig. 2. Diagram of the average flow speed of the fed liquid on the porous deposit made of coal grains for various thicknesses of deposit layers and various volumes of fed liquid

Rys. 2. Diagram średniej prędkości przepływu nadanej cieczy na złoże porowate zbudowane z ziaren węglowych dla różnych grubości warstwy złoża i różnej objętości nadanej cieczy

Analysis of the diagram - Figure 2, indicated that for the same volume of the fed mixture, the flow speed is respectively higher when the deposit thickness is smaller, hence the deposit puts up smaller resistance.

Therefore, with the calculated value of constant $b_{2}$ you can substitute this value with the general filtration equation - equation 1 , in the notation of the second part, in the denominator corresponding to deposit resistance $R_{Z}$ according to equation 5 , and with experimentally measured volume flow $V$, you can calculate constant $b_{1}$ from equation 7 . This will be the object of further research of the authors as well as next publication concerning this cycle, assuming current lack of the deposit's silting-up, that is assuming constant porosity of deposit $\varepsilon_{Z}$ appearing in equation 5. Further step to prepare such a cycle of publications will be the analysis of the filtration process with silting-up of the deposit, and then deposit porosity 
appearing in equation 5 will change, and - strictly speaking - reduce, while, at the same time, the volume of sediment accumulated in the deposit will be smaller $\left(V \cdot \beta_{N}\right)$, which is the result of the silting-up.

\section{Conclusions}

Certain general conclusions can be presented on the basis of the conducted basic tests and the theoretical analysis of fluid flow through the porous layer, as well as filtration process of the mixture of liquid and solid given by this porous layer spilt on the filtration mesh without the silting-up process of the deposit:

- it is possible to construct gravitational deposit filters with the deposit layer built from coal grains used for the filtration process of suspensions coming from mechanical processing of the coal;

- it is possible to use the general equation for filtration, here gravitational filtration, through the filtration mesh with the deposit built on this mesh if we determine - for given conditions of the process - constant values appearing in the resistance equations of the mesh, deposit and sediment accumulated on the deposit; these resistances appear in the denominator of the general filtration equation defining the volume outlay, and in the numerator of this equation there is pressure which constitutes the liquid pressure on the porous deposit in this process;

- determination of constant filtration mesh $t$ ' appearing in the mesh resistance equation shall be calculated according to the formula specified in this publication, after the previous performance of an experiment concerning flow of liquid (one-phase system) through the filtration mesh, and then the flow of liquid through the deposit spilt on the filtration mesh;

- only after conducting the activities and calculations defined in conclusion 3 you can conduct the experiment concerning filtration of the mixture by the deposit spilt on the filtration mesh, and knowing the value of volume outlay $V$ on the basis of these tests, you can calculate - from the derived equation 7 - the value of constant $b_{1}$ appearing in the sediment resistance equation (equation 2);

- with all the known values of constant filtration mesh $t^{\prime}$, constant $b_{2}$ present in the equation used for determination of deposit resistance (here: incompressible deposit) and knowing the value of constant $b_{1}$ present in the equation for sediment resistance, you can use general equation of filtration 1 for designing the gravitational filtration node in the water-silt circulation. 


\section{REFERENCES}

Aniszewski, A. 2013. Description and verification of the contaminat transport models in groundwater (theory and practice). Archives of Environmenal Protection Vol. 39, No. 3, pp. 3-21.

Dahlstrom, D.A. 1954. Theory and practice of filtration. International Congress on Mechanical Processing. Essen.

Guang-Wei et al 2015 - Guang-Wei, Zhang, Hu-Yuan, Zhang, Jin-Fang,Wang, Lang, Zhou, Ping, Liu and Xiao, Jang. 2015. Labory investigation of self-healing propertities on geosynthetic clay liners with flaw. Archives of Environmental Protection Vol. 41, No. 1, pp. 53-58.

Gumińska, J. 2007. The influence of microfloc age on its strength and sorption capacity. Environmental Protection Engineering No. 1, pp. 5-14.

Hewelke et al. 2014 - Hewelke, E., Szatyłowicz, J., Gnatowski, T. and Oleszczuk, R. 2014. Zmienność przestrzenna uwilgotnienia hydrofobowej gleby organicznej w warunkach przepływu preferencyjnego [Spatial variability of humidity of the hydrophobic organic soil in the conditions of preferential flow]. Rocznik Ochrona ŚrodowiskaAnnual Set the Environment Protection vol. 16, pp. 580-607 (in Polish).

Kabsch-Korbutowicz, M. and Urbanowska, A. 2009. Proces MIEX®DOC jako metoda przydatna do wstępnego oczyszczania wody przed procesem filtracji na membranach ceramicznych [MIEX ${ }^{\circledR D O C}$ process as a method used for pre-treatment of water before the filtration process on ceramic membranes]. Rocznik Ochrona Środowiska - Annual Set the Environment Protection vol. 11, pp. 595-606 (in Polish).

Kliber, S. and Wiśniewski, J.A. 2009. Membranowy proces wymiany anionów jako metoda zmiany składu jonowego wody [Membrane process of anion exchange as the method for changing water ion composition]. Rocznik Ochrona Środowiska - Annual Set the Environment Protection vol. 11, pp. 985-994 (in Polish).

Ostrowska et al. 2013 - Ostrowska, K., Janczukowicz, W., Radziewicz, J. and Mielcarek, A. 2013. Wpływ procesu filtracji na relacje między ilością substancji organicznych i związków biogennych w ściekach mleczarskich [Impact of the filtration process on relations between the volume of organic substances and biogenic compounds in milk sewers]. Rocznik Ochrona Środowiska - Annual Set on Environment Protection vol. 15, pp. 1411-1425 (in Polish).

Konieczny, K. 2015. Efektywność oczyszczania ścieków przy zastosowaniu reaktora membranowego [Effectiveness of sewage treatment with the use of membrane reactor]. Rocznik Ochrona Środowiska - Annual Set the Environment Protection vol. 17, pp. 1034-1052] (in Polish).

Piecuch, T. 2009. Równanie Darcy jako podstawa analizy teoretycznej szczególnych przypadków procesu filtracji [Darcy equation as the basis for theoretical analysis of special cases of the filtration process]. Rocznik Ochrona Środowiska - Annual Set the Environment Protection vol. 11, pp. 299-320 (in Polish).

Piecuch, T. 2010. Technika wodno-mułowa, urzadzenia i procesy [Water-silt technology, equipment and processes]. WNT, Warszawa (in Polish).

Piekarski, J. 2011. Zastosowanie metod numerycznych do modelowania procesu filtracji grawitacyjnej [Application of numerical methods for modelling of gravitational filtration process]. Rocznik Ochrona Środowiska-Annual Set the Environment Protection vol. 13, pp. 315-332 (in Polish).

Rychlewska et al. 2015 - Rychlewska, K., Konieczny, K. and Bodzek, M. 2015. Pervaporative desulfurization of gasoline-separation of thiophene/n-heptane mixture. Archives of Environmrntal Protection Vol. 41, No. 2, pp. 3-11.

Tomaszewska, B. 2011. The Use of Ultrafiltration and Reverse Osmosis in the Desalination of Low Mineralized Geothermal Waters. Archives of Environmental Protection vol. 37, No. 3. 
WYZNACZENIE WSPÓŁCZYNNIKA PRZEPUSZCZALNOŚCI

DLA ZŁOŻA FILTRACYJNEGO ZBUDOWANEGO Z ZIAREN WEGLOWYCH

\author{
Słowa kluczowe \\ węgiel kamienny, proces filtracji, stała oporu złoża
}

Streszczenie

W pracy przedstawiono metodę wyznaczania stałego współczynnika $b_{2}$, występującego w równaniu filtracji (1), jak również poprzez określenie wartości oporu osadu $R_{O}$.

W rozważaniach założono brak ściśliwości tego złoża, co oznacza, że porowatość złoża jest stała. Przy takim założeniu, stały współczynnik $b_{2}$ jest równoważny ze współczynnikiem przepuszczalności, co ma miejsce w powszechnie znanych i akceptowanych równaniach - jako podstawowego równania - dla przepływu płynu przez porowatą warstwę, według Darcy (Piecuch 2009, 2010).

Badanie te ujęte w tym artykule, z cyklu podstawowych badań procesu filtracji, stanowią kolejną pracę autorów, opublikowanych w Roczniku Ochrona Środowiska (Annual Set the Environmental Protection), a także w czasopiśmie Gospodarka Surowcami Mineralnymi (Mineral Resources Management), do których czytelnika zainteresowanego tymi problemami odsyłamy.

Cykl publikacji będzie badać możliwości korzystania z filtrów grawitacyjnych złożowych, w którym porowate złoże utworzone zostanie ze zbioru ziarn węgla, podczas gdy mieszanina będzie zawierać ziarna węgla z procesu produkcyjnego.

DETERMINATION OF TRANSMISSION COEFFICIENT FOR THE FILTRATION DEPOSIT MADE OF COAL GRAINS

\title{
Keywords
}

hard coal, filtration process, sediment resistance $R_{O}$

Abstract

The study presents the method of determining constant coefficient $b_{2}$, occurring in general filtration equation (1), in the second part of the denominator, that is in the expression for deposit resistance

In the considerations, lack of the deposit's compressibility was assumed, which means that the deposit porosity is constant. With such an assumption, constant coefficient $b_{2}$ is equivalent with transmission coefficient, which occurs in commonly known and accepted equation - as the baseline equation - for fluid flow through a porous layer according to Darcy (Piecuch 2009, 2010).

This study is another publication in the cycle of basic tests of the filtration process which constitute next publications of the authors, published in Rocznik Ochrona Środowiska [Annual Set the Environmental Protection] as well as in the magazine Gospodarka Surowcami Mineralnymi [Mineral Resources Management], to which the reader interested in these problems can refer. 
Another study will be the publication discussing the filtration process with the creation of sediment on the filtration deposit, hence in the general filtration equation (1) the value of sediment resistance $R_{O}$ will appear in the denominator.

Relevant cycle of publications will study the possibilities of use of gravitational deposit filters in which the porous deposit will be the set of coal grains, while the fed mixture will also be the post-production suspension of coal grains. 